\title{
М.В. СОЯОДИЯОВ
}

аспирант кафедры градостроительства

Самарский государственный архитектурно-строительный университет

\section{РОССИЙСКИЙ МОНОГОРОД КАК КРИЗИСНОЕ ЯВ АЕНИЕ}

\author{
THE RUSSIAN MONOCITY AS THE CRISIS PHENOMENON
}

В статье автор ставит проблему российского моногорода как кризисного явления.

Ключевые слова: моногорода, Тольятти, кризис.

9 сентября 1995 г. А.И. Солженицын посетил город Тольятти. Во время встречи с населением он вспомния дюбопытный эпизод из жизни: “Я здесь, в Ставрополе Волжском, был впервые в 1939 году. Я был студентом и вместе со своим другом мы спускались по Волге - просто лодку купили в Казани и спускались по Волге. Пристали. И пошли ходить по этому городу, где улицы были песчаные. Вязди мы в песках - такие улицы были. Смотрели и думали - какой чудный город, с каким историческим прошлым и дыханием"[1, с. 49]. Новый город Тольятти словно на обломках затонувшей Атлантиды был построен в порыве всеобщего энтузиазма людей, видевших в стремительно сооружавшихся гигантах реальные ростки социализма, и истории тут практически не нашлось места. Поэтому Тольятти можно смело описывать выражениями из книги Рема Коолхаса “S,M,L,XL": “Город - генерик - это город, освобожденный от гравитации центра, от смирительной рубашки идентичности; Город-генерик разрывает этот деструктивный цикл зависимости: в нем нет ничего, кроме отражения актуальных потребностей и актуальных возможностей; Это город без истории; Город-генерик - это фрактал, бесконечное повторение одного и того же простого структурного модуля; Наиболее оригинальное нововведение Города-генерика состоит в том, что он просто избавляется от всего, что не работает, от всего, что пережило пору своей полезности" [2, с. 172]. Главная беда заключается в том, что в последнее время ненужными оказались как жители, так и оригинальное своеобразие Автограда - самого крупного моногорода России. Что же мешает ему развиваться, быть привлекатедьным и комфортным? Вот вопросы, ответы на которые еще только предстоит найти.
In article the author puts a problem of the Russian monocity as crisis phenomenon.

Key words: monocities, Togliatti, crisis.

Проблема моногородов стала актуальной задолго до начала экономического кризиса. С его наступлением сырьевая ориентация или низкий уровень передела производимой продукции профильных градообразующих предприятий обусловили резкий спад производства, за которым последовало высвобождение большого количества рабочей силы. Вследствие низкого уровня диверсификации производств, моногорода оказадись на грани экономической и социальной катастрофы [3, с. 10].

Следствием стал ряд акций протеста, которые в течение года провели жители монопрофильных поселений, оказавшихся в безвыходном положении (наиболее известными являются забастовки в Пикалево и Светлогорье). Все это заставило федеральные и региональные власти обратить особое внимание на проблему моногородов. Был проведен ряд форумов, конференций, кругдых столов, посвященных данной проблематике. Результатом стали выработка мер и алгоритмов поддержки моногородов, выбор субъектов поддержки, а также выбор первых «горячих точек» - моногородов, которым помощь со стороны Федерации будет оказана в первоочередном порядке. Министерством регионального развития РФ было выделено 335 моногородов. На их долю приходится порядка 40 \% суммарного ВВП Российской Федерации. В Самарской области доля населения, проживающего в моногородах, достигает $28 \%$, что говорит о значимости генерации подходов и методов, позволяющих уйти от пагубных последствий монопрофильной ориентированности [3, с. 8].

Ключевыми факторами сбалансированного успешного развития в наши дни являются образование, благополучная демография, качество жизни, диверсифицированная экономика, инновативная среда, малые и средние предприятия, наличие от- 
раслей экономики будущего - все эти пункты в моногородах переживают не лучшие времена. Уровень качества жизни человека - важнейший показатель благополучия общества в целом.

В наиболее общем виде качество жизни представляет собой показатель социального развития. Необходимо подчеркнуть, что качество жизни многомерное понятие. Исключительно на концептуальном уровне оно включает в себя множество разнородных составляющих социального развития, по преимуществу не сводимых друг к другу. Качество жизни следует отдичать от терминологически и содержательно близкого понятия уровня жизни. Уровень жизни - показатель, отражающий благосостояние населения, сконцентрирован на подсчете объема доходов граждан и степени удовлетворения базовых потребностей. В сравнении с ним качество жизни - гораздо более широкий показатель, вкдючающий в себя оценку благосостояния в числе прочих критериев качества жизни, но также учитывающий и еще ряд показателей удовлетворения разного рода потребностей (здравоохранение, социальное обеспечение, транспорт, связь и коммуникации, обеспеченность учреждениями культуры и т.д.). Качество жизни - степень удовлетворения некоторого базового набора материальных и духовных потребностей индивида, характеризуемая, с одной стороны, определенным уровнем благосостояния, с другой - наличием необходимой инфраструктуры и прочих условий для удовлетворения этих потребностей [4].

Решение проблем моногородов осложняется нехваткой специалистов по данному вопросу, а также устоявшимися стереотипами. Всевозможные бизнесинкубаторы, бизнес-парки, особые экономические зоны - должны давать ожидаемые результаты, но смеем предположить, что это далеко не единственно возможные решения. Следует систематизировать и обобщить международный опыт, учитывая как провальные, так и удачные примеры.

Среди монопрофильных городов можно выдедить две категории: депрессивные и прогрессивные. Прогрессивные города - спутники крупных конгломератов; обладатели уникального потенциала; города, вблизи которых проходят крупные трассы; города, которые могут перепрофилироваться под новое инновационное сельское хозяйство. Самым крупным российским моногородом явдяется Тодьятти с населением 719500 человек (2010 г.), при этом наметилась тенденция убыли горожан: за 7 первых ме- сяцев 2011 г. количество тольяттинцев сократилось на 492 человека. Специалисты отмечают, что это произошло за счет миграции, а также естественной убыли населения. Тодьятти по многим параметрам никак не должен явдяться депрессивным. Однако статистика последних иет дает мадоутешительные сведения [5]. Поэтому июбые попытки теоретического осмысления феномена моногородов в целом и в частности на примере г.Тодьятти - весьма актуальны и необходимы.

Не стоит полагать, что моногорода существуют тодько дишь в России. За рубежом они имеют несколько иные названия: one-industry town, factory town, mill town, company town, mining town, railway town, resource town. Примером, демонстрирующим, что монопрофильность сама по себе не является проблемой, является опыт германского города Ингодьштадт. Ингодьштадт (Ingolstadt) - второй по величине город Верхней Баварии после Мюнхена (Германия), возник в XIII в. В настоящее время население города составляет 123 тыс. жителей. Градообразующим предприятием Ингольштадта является компания Audi [3].

С наступлением всемирного экономического кризиса стратегия городских властей заключилась в следующем.

Bo-nервых, была сделана ставка на поддержание уже имеющихся сильных компаний, ориентированных на внешние рынки (т.е. компанию Audi, а также известных предприятий-смежников, таких как EDAG, Peguform, Continental Automotive Systems и др.), в т.ч. посредством поддержки Яогистического центра (GVZ).

Bo-вторых, был сделан упор на создание «высококачественных» рабочих мест и следование инновационному сценарию развития города.

B-mретьих, наряду с разумной экономической политикой основного работодателя, был запущен новый современный железнодорожный грузовой вокзал.

Основная причина успешного развития моногорода Ингодьштадт в период кризиса закдючается в том, что градообразующее предприятие представдяет собой крупного игрока в автомобилестроительной отрасли, ориентированного на внешние рынки, а также на разработку и внедрение инновационных технологий. Кроме того, в условиях глобадьной экономической нестабильности конкурентным преимуществом компании явилась ориентация на сегмент «премиум», который оказался 
одним из наиболее устойчивых к кризисным явлениям сегментов. Простая и эффективная позиция администрации Ингодьштадта - развитие и без того сильных сторон города.

Еще одним любопытным примером явдяется город-побратим Тодьятти - г.Фдинт, штат Мичиган, известный такой автомобильной компанией, как “General Motors". C последнего десятилетия местные усилия по борьбе с негативными последствиями монопрофильности промпредприятий нацелены на диверсификацию экономики за счет привлечения мелких производителей на свободные производственные площади и налоговые стимулы. Огромные пустующие площади отдаются иогистическим компаниям. Интенсивно развиваются учебные заведения. Несмотря на принятые меры, население города неуклонно сокращается (на 9,6 \% с 2000 по 2008 гг.), и в 2008 г. Флинт бы внесен журналом Forbes в список 10 наиболее быстро умирающих городов США [3]. В городе местные власти пошли по пути минимизации убытков. Проводится программа «сокращения города» (urban shrinkage), где сравнивают с землей малозаселенные районы и разбивают на их месте парки. Другим вариантом применения такого подхода является сокращение числа муниципалитетов в целях повышения налоговых доходов и экономии расходов на полицию, пожарную охрану, водо- и электроснабжение.

Остается неразрешенной проблема в городе Детройте. За несколько лет население сократилось с 910 тыс. до 750 тыс. человек. На декабрь 2010 г. - безработица составдяет $19 \%$, а в городской агломерации - 11 \%. Почти 34 \% жителей Детройта проживают за чертой бедности [6].

Наиболее успешными оказались города, в которых прослеживалась высокая заинтересованность развития территории со стороны местных властей и налаживание тесной кооперации с градообразующим предприятием. Поддержка “профильных" промышленных предприятий города в конечном итоге оказывалась малопродуктивной и неэффективной. Значительный прогресс наблюдается в тех поселениях, где основные усилия были направлены на стимулирование предпринимательства: курсы переподготовки, организация бизнес-инкбаторов, создание новых производств градообразующим предприятием, надоговые дьготы. Эффективными явдяются меры по развитию образовательного и научного сектора (университеты, исследовательские центры и т.д.). Развитый образовательный сектор явдяется крупным работодателем, что помогает снизить безработицу в городе. Также могут быть предложены проекты по реализации туристического и рекреационного потенциала: развитие инфраструктуры, активный пиар достопримечательностей, экологические мероприятия. Главная задача в решении проблемы моногородов должна закдючаться в смещении акцентов в структуре экономики города и переориентации на сектор услуг, также важно создание положительного бренда города.

Моногород Тодьятти является феноменом в сети окружающих производств, расселения и природных факторов. Поэтому автор предлагает исследование проблемы Тодьятти по следующим направлениям:

Гуманитарное - должно дать представдение о действительном количестве и качестве учреждений культуры.

Научные исследования и инновации - актуализируют уже решенный вопрос создания в Тольятти Особой экономической зоны промышленнопроизводственного типа.

Искусство, арт-девелопмент - изучает такой аспект как конкурентоспособность города, где показателями служат туристическая привлекательность, узнаваемость, возможность реализации творческого потенциала жителей.

Социодогические исследования дадут представление о мнении местных жителей города.

Диверсификация производств - методика позволяющая создавать новые производства на базе уже имеющегося градообразующего предприятия.

Событийный туризм - анализ местных уникальных особенностей в целях организации массовых праздников и фестивалей федерадьного уровня.

Снова возвращаясь к г.Тодьятти, приходит мысль о множестве сокрытых тайн, «микротрещин» в урбанистической мысли, которые еще только предстоит отрефлексировать. Обновление постулатов, пересмотр угла зрения на проблему, на методы и инструменты - вот что заставляет добрые струны научного познания зазвучать.

Таким образом, автор надеется исследовать процессы, способствующие выводу кризисного моногорода на путь устойчивого и перспективного развития. 


\section{БИБЛИОГРАФИЧЕСКИЙ СПИСОК}

1. А.И Солженицын и Самара [Текст] / науч. ред. П.С. Кабытова. - Самара: Изд-во “Самарский университет", 2008.- 139 с.; илл.

2. Рем Коолхас. Город-генерик [Текст] // Проект International. - 2010. - № 25 (1). - C. 172-187.

3. Моногорода: расселить нельзя диверсифицировать? [Текст] // Анадитические доклады (Екатеринбург,
23-24 апреля 2010 г.) - Екатеринбург: Изд-во УрГУ, 2010. - C. 74 .

4. http://iri.local-group.ru

5. http://chronograf.ru/articles/?num=195\&a=5284

6. http://goroda-prizraki.narod.ru/goroda_detroyt. html

(C) Солодилов М.В., 2011 